\title{
Conditions of Diamond Formation beneath the Sino-Korean Craton: Paragenesis, Temperatures and the Isotopic Composition of Carbon
}

\author{
Zhang, A. ${ }^{1,2}$, Griffin, W.L. ${ }^{2,3}$, Ryan, C.G. ${ }^{3}$ and Andrew, A. ${ }^{4}$ \\ 1. Flat 1707 , Building 8 , Maolinju, Muxidi 100038 , China \\ 2. GEMOC National Key Centre, Macquarie University, NSW 2109, Australia \\ 3. CSIRO Exploration and Mining, P.O. Box 136, North Ryde, NSW 2113, Australia \\ 4. CSIRO Div. of Petroleum Research, P.O. Box 136, North Ryde, NSW 2113, Australia
}

Mineral inclusions (23 pyrope garnets, 30 chromites) have been extracted from 28 diamonds selected from the Pipe \#50 kimberlite in Liaoning Province, and the pipes of the Shengli \#1 and Hongqi \#6 kimberlites in Shandong province. These inclusions, and several from the collection of Meyer et al. (1994), have been analysed for major elements using EMP and for trace elements using the proton microprobe. Carbon-isotope compositions have been measured on 44 diamonds ( 23 from Liaoning, 21 from Shandong), of which 32 contained identified inclusions.

\section{Mineral Inclusions}

Most of the pyrope garnets in concentrates from both areas are strongly subcalcic, with $\mathrm{CaO}=1.6-4.5 \%$ and $\mathrm{Cr}_{2} \mathrm{O}_{3}=7-17 \%$ (Fig. 1). Diamonds from both areas also contain a population of

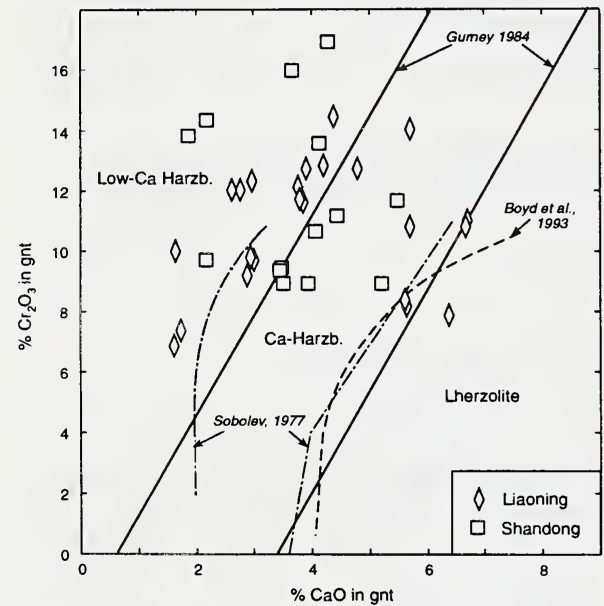

Fig. $1 \mathrm{CaO}-\mathrm{Cr}_{2} \mathrm{O}_{3}$ plot for Chinese diamond-inclusion garnets (this work, Meyer et al. (1994). mildly subcalcic garnets with $\mathrm{CaO} 4.8-5.8 \%$ and $\mathrm{Cr}_{2} \mathrm{O}_{3}$ 8-14\%; low $\mathrm{Na}$ contents indicate that these are derived from harzburgites, rather than high- $\mathrm{Na}$ lherzolites. The Liaoning sample contains three diamonds with inclusions of lherzolitic garnet $\left(\mathrm{CaO}\right.$ ca $\left.6-7 \%, \mathrm{Cr}_{2} \mathrm{O}_{3} 8-11 \%\right)$. Several stones contain $>1$ inclusion of $\mathrm{Cr}$-pyrope; in most cases these are very similar in composition, but others show ranges in $\mathrm{CaO}$ content (largest range 3.0$4.8 \%$ ) and/or $\mathrm{Cr}_{2} \mathrm{O}_{3}$ content (9-9.5\%). Most of the pyrope inclusions are depleted in $\mathrm{Y}(<6 \mathrm{ppm})$ and $\mathrm{Zr}(<30 \mathrm{ppm})$, similar to most pyrope garnets in concentrates and diamonds. However, in both areas some harzburgitic garnets are enriched in $\mathrm{Zr}$ (40-110 ppm) but not $Y$; similar garnets are common in concentrates from both areas, especially Shandong. Lherzolitic garnets from Liaoning, and one harzburgitic garnet from Shandong, have high Y (16-24 ppm) and Zr (50$80 \mathrm{ppm}$ ) contents. Sr contents are high (up to 40 ppm; average $15 \mathrm{ppm}$ ) in garnets from both areas; this is characteristic of diamond-inclusion garnets

worldwide (Griffin et al., 1992,1993). Where >1 inclusion occurs in a single stone, trace-element contents are generally similar, but in some cases $\mathrm{Y}$ may vary by a factor of 2 , and in Ni by $5 \mathrm{x}$.

Chromite inclusions are high in $\mathrm{Cr}$ and low in $\mathrm{Al}$, and most are similar to other chromite inclusions worldwide. However, 6 chromites in one diamond from the Hongqi 6 kimberlite all have unusually high $\mathrm{TiO}_{2}$ contents $(0.8-1 \%)$, high and variable $\mathrm{Zr}$ contents $(<1-70 \mathrm{ppm}$, average 40 ppm) and modest $\mathrm{Nb}$ contents $(2-7 \mathrm{ppm}$ ). The high $\mathrm{Ti}, \mathrm{Zr}$ and $\mathrm{Zr} / \mathrm{Y}$ of these damond inclusions mirrors the geochemical signature of xenocryst garnets and chromites from this kimberlite, which is related to extensive mantle metasomatism accompanied by the formation of LIMA minerals (Zhou et al., 1994). A similar pattern is seen in 7 chromites from one Liaoning stone, where major elements show little variation, but $\mathrm{Zr}$ contents vary from $13-93 \mathrm{ppm}$ (average $55 \mathrm{ppm}$ ) and $\mathrm{Nb}<1-8 \mathrm{ppm}$ ), but $\mathrm{TiO}_{2}$ contents are low (0.2\%). Chromites from both areas show a bimodal distribution of $\mathrm{Ga}$ and $\mathrm{Ga} / \mathrm{Ni}$, suggesting that chromites of both lherzolitic and harzburgitic parageneses are present. 


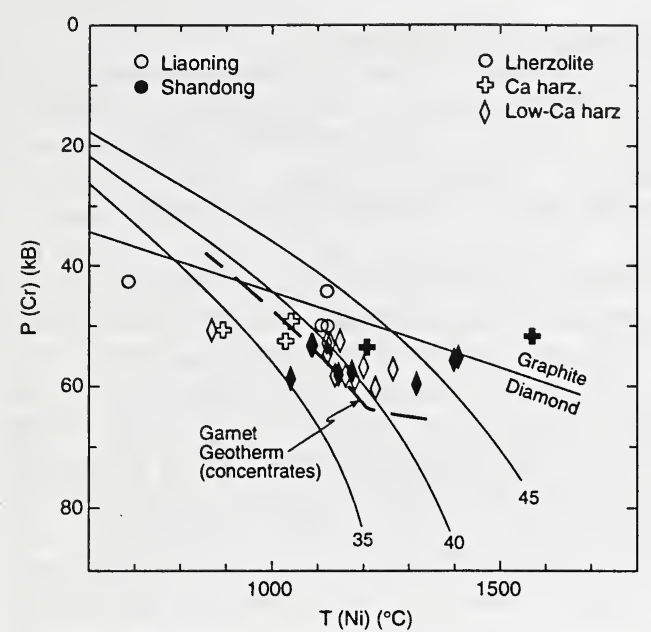

2. $\mathbf{P}_{\mathrm{Cr}}-\mathbf{T}_{\mathrm{Ni}}$ plot, diamond-inclusion garnets
Garnet Geotherms (Ryan et al., 1996) for the Shandong and Liaoning kimberlites are similar, and lie between 35 and $40 \mathrm{~mW} / \mathrm{m}^{2}$ conductive models (Griffin et al., 1998). However, the concentrate garnets from the two areas show quite different temperature distributions; most nickel temperature $\left(\mathrm{T}_{\mathrm{Ni}}\right)$ values from Liaoning kimberlites are $<1200{ }^{\circ} \mathrm{C}$, while most from Shandong kimberlites are $1100-1450{ }^{\circ} \mathrm{C}$, reflecting a higher degree of interaction with asthenosphere-derived melts near the base of the Paleozoic lithosphere beneath Shandong. These temperature differences are mirrored in the distribution of $\mathrm{T}_{\mathrm{Ni}}$ (in garnet) for the diamond inclusions of the two areas; temperatures for Liaoning garnets and chromites average $1025^{\circ} \mathrm{C}$, while those for Shandong average $1240^{\circ} \mathrm{C}$. In particular, the $\mathrm{T}$ distributions of the diamond inclusions closely match the $\mathrm{T}$ distributions of harzburgitic garnet and chromite xenocrysts from heavy mineral concentrates at each locality. P-T estimates for the inclusion garnets are consistent with the geotherm derived from the concentrates (Fig. 2) but several from Shandong lie well above this geotherm.

Several diamonds with $>1$ inclusion record large differences in $\mathrm{T}_{\mathrm{Ni}}$ or $\mathrm{T}_{\mathrm{Zn}}$. Replicate analyses show that the temperatures of individual inclusions can be reproduced within $\pm 30-40{ }^{\circ} \mathrm{C}$; the largest ranges in $\mathrm{T}_{\mathrm{Ni}}$ are $890-1155,685-1105,865-1120{ }^{\circ} \mathrm{C}$ at Liaoning, and $1085-1410{ }^{\circ} \mathrm{C}$ at Shandong. The lowest of these temperatures are within the diamond stability field on the derived geotherm. Three subcalcic pyropes $\left(\mathrm{Cr}_{2} \mathrm{O}_{3} 9.2-9.8 \%, \mathrm{CaO} 3 \%\right)$ in one Liaoning diamond contain $<6 \mathrm{ppm} \mathrm{Ni}$ $\left(\mathrm{T}_{\mathrm{Ni}}<550^{\circ} \mathrm{C}\right.$, in the graphite stability field), suggesting that they have not been in equilibrium with typical mantle olivine. Five chromites from one Liaoning diamond show a range in $\mathrm{T}_{\mathrm{Zn}}$ of $970-1330$ ${ }^{\circ} \mathrm{C}$, while $\mathrm{T}_{\mathrm{Zn}}$ of four chromites from one Shandong stone are probably similar within error (1105$\left.1170^{\circ} \mathrm{C}\right)$.

\section{Carbon Isotopes}

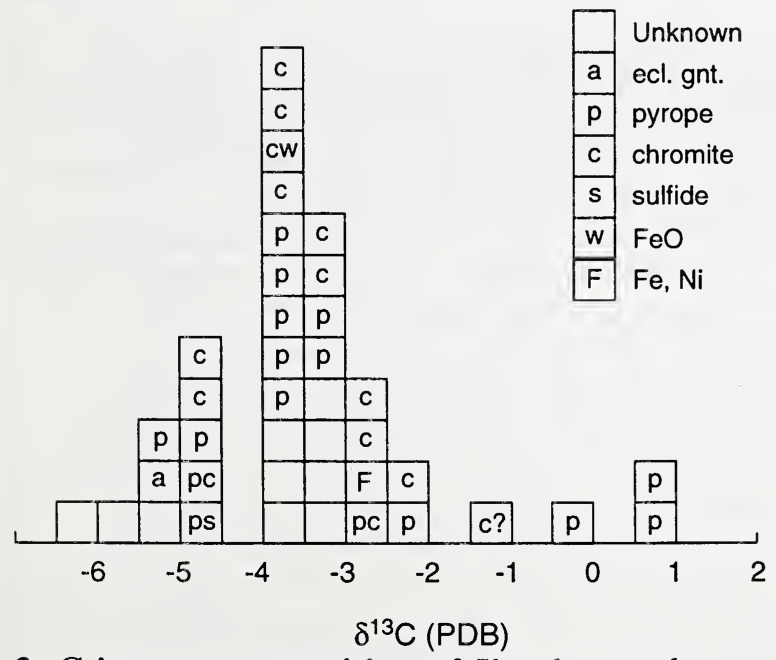

3. C-isotope composition of Shandong and

Liaoning diamonds (inclusions labelled)
The $\partial^{13} \mathrm{C}$ values of 44 diamonds range from +0.9 to $-6.0 \%$ (average -3.40 $\%$, median $-3.67 \%$; Fig. 3). Diamonds with identified peridotitic inclusions range from +0.9 to $-5.37 \%$ (average $-3.09 \%$, median $-3.55 \%$ ). There is no obvious correlation between $\partial^{13} \mathrm{C}$ and inclusion type, and no correlation of $\partial^{13} \mathrm{C}$ with temperatures estimated from mineral inclusions. However, there is a broad correlation between the $\mathrm{CaO}$ content of $\mathrm{Cr}$ pyrope inclusions and $\partial^{13} \mathrm{C}$; the heaviest Ca garnets. carbon is found in stones with very low- 


\section{Discussion:}

The inclusions in the diamonds from North China are similar in most respects to those found in kimberlitic diamonds worldwide; they are dominantly of the harzburgitic paragenesis, but show a continuous range to less depleted lherzolitic parageneses. Most of the diamonds appear to have grown under P-T conditions similar to those recorded by xenocryst garnets, which record a conductive geotherm well within the range found beneath most Archean cratons at the time of kimberlite emplacement (Paleozoic, in the present cases). However, the large $\mathrm{T}$ range recorded by multiple inclusions in some diamonds suggests that diamond growth was accompanied by at least local T fluctuations well above the stable ambient temperature. The apparent similarity of thermal conditions in Paleozoic time and during diamond growth may simply reflect the equilibrium P-T conditions in a depleted lithospheric root. However, the trace-element characteristics of some inclusions mimic metasomatic signatures in concentrate garnets and chromites from the host kimberlite. These signatures, and in particular the LIMA-associated metasomatism in the Hongqi-6 kimberlite, generally are regarded as relatively young overprints on ancient depleted mantle (Zhou et al., 1994; Griffin et al., 1996). The similarity of these signatures in concentrate and diamondinclusion minerals suggests either that these metasomatic signatures are ancient, or that the diamonds have grown at a relatively late stage of the lithospheric history. However, the observed relationship between $\partial^{13} \mathrm{C}$ and the $\mathrm{Ca}$ content of garnet inclusions implies that the isotopic composition of carbon in harzburgitic rocks somehow is related to the primary depletion process, which suggests ancient formation of the diamonds.

\section{References}

Griffin, W.L., Gurney, J.J. and Ryan, C.G., 1992, Variations in trapping temperatures and trace elements in peridotite-suite inclusions from African diamonds: evidence for two inclusion suites, and implications for lithosphere stratigraphy, Contr. Min. Pet., 110, 1-15.

Griffin W.L., Sobolev, N.V., Ryan C.G., Pokhilenko, N.P, Win, T.T. and Yefimova, Y., 1993, Trace elements in garnets and chromites: diamond formation in the Siberian lithosphere, Lithos, 29, 235-256.

Griffin, W.L., Smith, D., Ryan, C.G., O'Reilly, S.Y. and Win, T.T., 1996, Trace element zoning in mantle minerals: Metasomatism and thermal events in the upper mantle, Canad. Mineral., 34, 1179-1193.

Griffin, W.L., Zhang A., O'Reilly, S.Y. and Ryan, C.G., 1998, Phanerozoic evolution of the lithosphere beneath the Sino-Korean Craton, In: Mantle Dynamics and Plate Interactions in East Asia (Flower, M., Chung, S.L., Lo, C.H. and Lee, T.Y., eds). Amer. Geophys. Union Spec. Publ., in press

Meyer, H.O.A., Zhang, A., Milledge, H.J. and Mendelssohn, M.J., 1994, Diamonds and inclusions in diamonds from Chinese kimberlites, In: H.O.A. Meyer and O.H. Leonardos (eds). Diamonds: Characterization, Genesis and Exploration. CPRM Spec. Publ. 1B, 98-105.

Ryan, C.G., Griffin, W.L. and Pearson, N.J., 1996, Garnet Geotherms: a technique for derivation of P-T data from Cr-pyrope garnets, Jour Geophys. Res., 101, 5611-5625.

Zhou, J., Griffin, W.L., Jaques, A.L., Ryan, C.G. and Win, T.T., 1994, Geochemistry of diamond indicator minerals from China, In: H.O.A. Meyer and O.H. Leonardos (eds). Diamonds: Characterization, Genesis and Exploration, CPRM Spec. Publ. 1B, 285-301. 